\section{Physical Properties of Processed Poultry Feather Fiber-containing Greenhouse Root Substrates}

\author{
Michael R. Evans ${ }^{1,3}$ and Leisha Vance ${ }^{2}$
}

ADDITIONAL INDEX WORDS. growing media, perlite, bark

SUMmaRY. A series of soilless root substrates was formulated to contain either $20 \%$ composted pine bark or perlite and $0 \%, 10 \%, 20 \%$, or $30 \%$ feather fiber, with the remainder being sphagnum peat. The substrates containing bark or perlite with $0 \%$ feather fiber served as the controls for the bark- and perlite-containing substrates respectively. For root substrates containing perlite, the inclusion of feather fiber increased the total pore space compared with the control substrate. For substrates containing bark, the inclusion of $10 \%$ or $20 \%$ feather fiber increased total pore space, but the inclusion of $30 \%$ feather fiber reduced total pore space. For substrates containing perlite, the inclusion of feather fiber increased the air-filled pore space compared with the control, and as the percentage feather fiber increased, airfilled pore space increased. For substrates containing bark, the inclusion of $10 \%$ or $20 \%$ feather fiber increased air-filled pore space, but air-filled pore space of the substrate containing $30 \%$ feather fiber was not different from the control. For all substrates, the inclusion of feather fiber reduced the water-holding capacity, but water-holding capacities for all substrates remained within recommended ranges. The bulk density of feather fiber-containing substrates was not different from the control except for the substrate containing $30 \%$ feather fiber with bark, which had a higher bulk density than its control without feather fiber. The difference in physical properties of the $30 \%$ feather fiber substrate with bark from its control substrate was attributed to the aggregation of the feather fiber when formulated with composted bark. Aggregation of feather fiber when blended into substrates at levels of $30 \%$ or higher would create difficulties in achieving uniform substrates.

S oilless root substrates (substrates) are commonly used in the production of containerized greenhouse and nursery crops (Nelson, 2003). Substrates are formulated from various organic and inorganic components to provide suitable physical and chemical properties as required by the specific crop and growing conditions (Bunt, 1988). One of the most common materials used in the formulation of substrates is sphagnum peat. Environmental concerns (Barkham, 1993; Buckland, 1993; Robertson, 1993) in the European Union (EU) and cost in markets such as Japan that are far from commercial sphagnum peat sources have generated significant interest in the development of new substrate components.

Most research on the development of new substrate components

Department of Horticulture, University of Arkansas, 315 Plant Science Building, Fayetteville, AR 72701

This project was supported by Tyson Foods, Springdale, Ark., and the Arkansas Agricultural Research and Extension Service.

${ }^{1}$ Associate Professor.

${ }^{2}$ Former Graduate Student.

${ }^{3}$ Corresponding author. E-mail: mrevans@uark.edu. has been focused on agricultural, industrial, and municipal waste products. Among these products are coconut coir (Evans and Stamps, 1996), cotton gin waste (Wang, 1991), waste paper products (Chong and Cline, 1993; Raymond et al., 1998), composted rice hulls (Laiche and Nash, 1990), kenaf (Wang, 1994), municipal sewage sludge (Klock-Moore, 1999, 2001), composted yard waste (Beeson, 1996), and various composted animal manures (Tyler et al., 1993). Some of these materials were not produced in large enough quantities to affect the market, whereas others were too expensive for their intended use. Some of these materials have proved to be unsuitable because of their high degree of variability and their likelihood of containing contaminants such as metal fragments, glass, lead, and mercury, whereas others have been used successfully locally, regionally, or in niche markets.

Poultry feathers are a significant waste material produced by the meat processing industry. About 2 billion pounds of feather remained as a byproduct of poultry production in 2002 (U.S. Department of Agriculture, 2003). Depending upon location and specific environmental regulatory requirements, feathers may be dried and ground for use in fertilizers (Choi and Nelson, 1996a, b; Hadas and Kautsky, 1994) and animal feeds (Brown and Pate, 1997; Moritz and Latshaw, 2001; Palmquist et al., 1993), burned or land filled. In the EU, many poultry producers pay for the disposal of waste feathers (M.R. Evans, unpublished).

Being made almost entirely of the protein keratin, feathers are strong, fibrous, biodegradable and contain $\approx 15 \% \mathrm{~N}$ by weight (Hadas and Kautsky, 1994).

Feathers were reported to have more surface area and to be more absorbent than plant fiber (McGovern, 2000). Keratin is made of complex proteins that are not easily broken down and remain in a relatively stable state (Tan and Tai, 1983). The large quantity available, their low cost, and their physical characteristics might serve to make poultry feather a desirable component for greenhouse substrates.

Evans (2004) demonstrated that ground poultry feather fiber could be used to grow several annual bedding plant species successfully when used in peat or bark-based substrates containing up to $30 \%$ ground feather fiber. However, no information was reported regarding how the inclusion of the feather fiber affected the physical properties of the substrates. The objective of this study was to determine whether the incorporation of feather fiber into sphagnum peatbased substrates significantly affected the physical properties of the resulting substrates.

\begin{tabular}{llll}
\hline $\begin{array}{l}\text { Units } \\
\begin{array}{l}\text { To convert U.S. to SI, } \\
\text { multiply by }\end{array}\end{array}$ & U.S. unit & SI unit & $\begin{array}{l}\text { To convert SI to U.S., } \\
\text { multiply by }\end{array}$ \\
\hline 29.5735 & $\mathrm{fl} \mathrm{oz}$ & $\mathrm{mL}$ & 0.0338 \\
2.5400 & inch $(\mathrm{es})$ & $\mathrm{cm}$ & 0.3937 \\
0.4536 & $\mathrm{lb}$ & $\mathrm{kg}$ & 2.2046 \\
1.7300 & $\mathrm{Oz} / \mathrm{inch}^{3}$ & $\mathrm{~g} \cdot \mathrm{cm}^{-3}$ & 0.5780 \\
$\left({ }^{\circ} \mathrm{F}-32\right) \div 1.8$ & ${ }^{\circ} \mathrm{F}$ & ${ }^{\circ} \mathrm{C}$ & $\left(1.8 \times{ }^{\circ} \mathrm{C}\right)+32$
\end{tabular}




\section{Materials and methods}

In cooperation with Tyson Foods (Springdale, Ark.), freshly processed poultry feathers were washed in water, drained, pressed in a screw press to remove excess water, and treated with a $30 \%$ hydrogen peroxide solution $(\mathrm{v} / \mathrm{v})$. The feathers were then chopped in a paper mill to produce feather fiber particles 0.5 to $1.0 \mathrm{~cm}$ long. During the grinding process, temperatures reached 66 to $68^{\circ} \mathrm{C}$. The resulting feather fiber had a moisture level of $\approx 55 \%$ (wt/wt). The feather fiber was immediately blended with unamended sphagnum peat (Sun Gro Horticulture, Bellvue, Wash.) to produce a 60 peat : 40 feather fiber composite $(\mathrm{v} / \mathrm{v})$. The composite material had a moisture level of $\approx 45 \%$ (wt/wt). It was necessary to blend the feather fiber with the peat immediately to reduce the moisture level to prevent the composting process and to prevent packing or clumping of the feather fiber before use in blending of the final root substrates.

The 60 peat : 40 feather fiber composite was blended with additional sphagnum peat and composted pine bark $(\approx \mathrm{l} \mathrm{cm}$ in diameter $)$ or horticultural grade perlite to produce substrates that contained either $20 \%$ perlite or $20 \%$ composted bark and a total of $0 \%, 10 \%, 20 \%$, or $30 \%$ feather fiber in the final root substrate (Table 1 ) with the remainder being sphagnum peat. A total of eight substrates were formulated.

The substrates were air-dried in a greenhouse at 32 to $35{ }^{\circ} \mathrm{C}$ until they no longer lost weight over a $24-\mathrm{h}$ period. The samples were rewetted with deionized water to a moisture level of $60 \%$ (wt/wt). They were then placed into plastic bags and allowed to equilibrate for $1 \mathrm{~d}$ to attain moisture uniformity. Substrates were packed into $350-\mathrm{mL}$ porometers $(3 \times 3$ inches $)$, and total porosity (volume per volume), air-filled pore space (volume per volume), waterholding capacity (volume per volume), and bulk density (weight per volume) were determined using procedures described by Byrne and Carty (1989) and Bilderback and Fonteno (1993).

Five replications of the eight substrates were evaluated. Singledf contrasts were conducted for each of the physical properties to determine whether significant differences occurred between the $0 \%$ feather fiber controls and the feather fibercontaining substrates.

\section{Results and discussion}

For substrates containing perlite, total pore space ranged from $80.3 \%$ to $86.0 \%$, with the inclusion of feather fiber increasing the total pore space compared with the perlite control substrate (Table 1). For substrates containing bark, total pore space ranged from $78.3 \%$ to $87.2 \%$. The inclusion of $10 \%$ or $20 \%$ feather fiber increased total pore space, but the inclusion of $30 \%$ feather fiber reduced total pore space. No difference in total pore space occurred overall between perlite and bark-containing substrates.

For substrates containing perlite, air-filled pore space ranged from $10.9 \%$ to $30.6 \%$ (Table 1 ). The inclusion of feather fiber increased the airfilled pore space compared with the perlite control substrate, and as the percentage feather fiber increased, air-filled pore space increased. Airfilled pore space ranged from $13.2 \%$ to $25.3 \%$ for substrates containing bark, and the inclusion of $10 \%$ to $20 \%$ feather fiber increased air-filled pore space compared with the bark control substrate. However, air-filled pore space of the bark-containing substrate with $30 \%$ feather fiber was not different from the bark control substrate without feather fiber.

The relatively large particle size and rigid nature of the feather fiber particles likely resulted in the increased total pore and air-filled pore spaces of all $10 \%$ and $20 \%$ feather fiber-containing substrates and the

Table 1. Total pore space, air-filled pore space, water-filled pore space, water-holding capacity, and bulk density of sphagnum peat-based substrates amended with feather fiber.

\begin{tabular}{|c|c|c|c|c|c|c|c|c|}
\hline \multicolumn{4}{|c|}{ Substrate components $(\% \mathrm{v} / \mathrm{v})$} & & \multirow{2}{*}{$\begin{array}{c}\text { Total pore } \\
\text { space } \\
(\% \mathrm{v} / \mathrm{v}) \\
\end{array}$} & \multirow{2}{*}{$\begin{array}{c}\text { Air-filled } \\
\text { pore space } \\
(\% \mathrm{v} / \mathrm{v})\end{array}$} & \multirow{2}{*}{$\begin{array}{c}\text { Water holding } \\
\text { capacity } \\
(\% \mathrm{v} / \mathrm{v})\end{array}$} & \multirow{2}{*}{$\begin{array}{c}\text { Bulk } \\
\text { density } \\
\left(\mathrm{g} \cdot \mathrm{cm}^{-3}\right)^{\mathrm{z}} \\
\end{array}$} \\
\hline Perlite & Bark & $\begin{array}{c}\text { Sphagnum } \\
\text { peat }\end{array}$ & $\begin{array}{c}\text { Feather } \\
\text { fiber }\end{array}$ & & & & & \\
\hline 20 & 0 & 80 & 0 & & 80.3 & 10.9 & 69.4 & 0.09 \\
\hline 20 & 0 & 60 & 20 & & 86.0 & 22.9 & 63.2 & 0.09 \\
\hline 20 & 0 & 50 & 30 & & 82.9 & 30.6 & 52.3 & 0.08 \\
\hline 0 & 20 & 60 & 20 & & 87.2 & 25.3 & 61.9 & 0.10 \\
\hline 0 & 20 & 50 & 30 & & 78.3 & 14.5 & 63.8 & 0.11 \\
\hline \multicolumn{4}{|c|}{ Significance } & df & & & & \\
\hline \multicolumn{4}{|c|}{ Substrate } & 7 & $* * *$ & $* * *$ & $* * *$ & $* * *$ \\
\hline \multicolumn{4}{|c|}{$0 \%$ feather fiber vs. $10 \%$ feather fiber perlite } & 1 & *** & $* * *$ & $* * *$ & NS \\
\hline \multicolumn{4}{|c|}{$0 \%$ feather fiber vs. $20 \%$ feather fiber perlite } & 1 & *** & $* * *$ & $* * *$ & NS \\
\hline \multicolumn{4}{|c|}{$0 \%$ feather fiber vs. $30 \%$ feather fiber bark } & 1 & *** & NS & $* * *$ & * \\
\hline \multicolumn{4}{|c|}{ Perlite vs. bark } & 1 & NS & $* * *$ & $* * *$ & $* * *$ \\
\hline
\end{tabular}

${ }^{2} 1 \mathrm{~g} \cdot \mathrm{cm}^{-3}=0.5780 \mathrm{oz} /$ inch $^{3}$

$\mathrm{Ns},+,+*+, * *+$ Nonsignificant or significant at $\mathrm{P}=0.05,0.01$, or 0.001 respectively 
$30 \%$ feather fiber-containing substrate with perlite by creating more and larger pores that drained after saturation. One possible reason for the observed decrease in total pore space and air-filled pore space in the bark-containing substrate with $30 \%$ feather fiber was the tendency of feather fiber to separate from the peat during final mixing of the substrates and to form aggregates. We observed that at low proportions of feather fiber, the feather fiber was more evenly distributed throughout the substrate, but at higher levels, aggregation of feather fiber occurred within the substrate. Feather fiber was hydrophobic (Fraser and Macrae, 1980), and when a substrate containing feather fiber aggregates was placed into porometers and filled with water, these aggregates tended to repel water and caused voids within the root substrate, which did not fill with water, and would have been represented as solids in the porometer tests. This aggregation of feather fiber was significant at $30 \%$ feather fiber in bark-containing substrates, but the perlite was a more coarse material that prevented significant aggregation at $30 \%$ feather fiber. Although, not included in this study, aggregation of feather fiber was observed in perlite-containing substrates at higher feather fiber proportions.

For substrates containing perlite or bark, water-holding capacity (volume per volume) ranged from $52.3 \%$ to $69.4 \%$ or $61.9 \%$ to $69.6 \%$ respectively (Table 1). For all substrates containing perlite or bark, the inclusion of feather fiber reduced the water-holding capacity. Water-holding capacity decreased in perlite-containing substrates as the percentage of feather fiber increased.

The decrease in water-holding capacity was correlated with an increase in air-filled pore space. As feather fiber increased, the percentage of larger pores increased and the percentage of smaller water-filled pores decreased, and thus water-holding capacity decreased.

Arnold Bik (1983) and Boertje (1984) recommended a minimum of $85 \%$ total pore space and at least $45 \%$ water-filled pore space. Bunt (1988) recommended an air-filled pore space of at least $10 \%$ to $20 \%$. Jenkins and Jarrell (1989) proposed optimal ranges of $60 \%$ to $75 \%$ for total pore space, $50 \%$ to $65 \%$ for water-holding capacity, and $10 \%$ to $20 \%$ for air-filled pore space. All the root substrates in this study would have been within one of the general recommendations with regard to total pore space and water-holding capacity. However, only the control root substrates without feather fiber and the root substrate containing $30 \%$ feather fiber and bark had an air-filled pore space within these recommended ranges. All other feather fiber-containing substrates had air-filled pore spaces above the recommended range. Because the higher air-filled pore space did not result in suboptimal water-holding capacities, the higher than recommended air-filled pore space should not be a significant problem in a greenhouse production environment. In fact, Evans (2004) reported that plants grown in feather fiber-containing substrates performed similarly to plants grown in control substrates without feather fiber.

The bulk density of perlitecontaining substrates ranged from 0.08 to $0.09 \mathrm{~g} \cdot \mathrm{cm}^{-3}$, and the inclusion of feather fiber did not affect bulk density (Table 1). The bulk density of bark-containing substrates ranged from 0.09 to $0.11 \mathrm{~g} \cdot \mathrm{cm}^{-3}$. For barkcontaining substrates, the inclusion of $10 \%$ or $20 \%$ feather fiber did not significantly affect bulk density, but the inclusion of $30 \%$ feather fiber increased bulk density. Overall, barkcontaining substrates had a higher bulk density than perlite-containing substrates.

The increase in the bulk density of bark-containing substrates with $30 \%$ feather fiber was correlated with the decrease in total spore space and, as with total pore space, may have been attributable to the feather fiber aggregates formed in this root substrate. Jenkins and Jarrell (1989) suggested optimal ranges for bulk density from 0.15 to $1.3 \mathrm{~g} \cdot \mathrm{cm}^{-3}$ for container mixtures. Although bulk density ranges of the feather substrates were less than the suggested ranges, they were still within bulk density ranges $\left(0.06-0.1 \mathrm{~g} \cdot \mathrm{cm}^{-3}\right)$ of sphagnum peat (Bunt, 1988).

\section{Conclusion}

The physical properties of most of the feather fiber-containing substrates differed from the $0 \%$ feather fiber control substrates, but the total pore space and the water-holding capacity values were within recommended ranges for greenhouse crops. Air-filled pore space was higher than recommended levels, but the higher than recommended air-filled pore space did not result in suboptimal water-holding capacities. Therefore, feather fiber could be used at rates up to at least $30 \%$ with peat and perlite substrates without negatively affecting the physical properties of the substrate. However, at 30\% feather fiber with peat and bark, aggregation or clumping of the feather fiber occurred during mixing of the final substrate. The tendency of feather fiber to form aggregates during substrate mixing would be problematic for substrate mixing companies or growers mixing their own substrates when attempting to ensure substrate uniformity, especially when using feather fiber at levels more than $20 \%$, depending upon the specific components being mixed with the feather fiber.

\section{Literature cited}

Arnold Bik, R. 1983. Substrates in floriculture. Proc. XXI Intl. Hort. Congr. 2:811-822.

Barkham, J.P. 1993. For peat's sake: Conservation or exploitation. Biodivers. Conserv. 11:1877-1887.

Beeson, R.C., Jr. 1996. Composted yard waste as a component of container substrates. J. Environ. Hort. 14:115-121.

Bilderback, T.E. and W.C. Fonteno. 1993. Impact of hydrogel on physical properties of coarse-structured horticultural substrates. J. Amer. Soc. Hort. Sci. 118:217-222.

Boertje, G.A. 1984. Physical laboratory analyses of potting composts. Acta Hort. 150:47-50.

Brown, W.F. and F.M. Pate. 1997. Cottonseed meal or feather meal supplementation of ammoniated tropical grass hay for yearly cattle. J. Anim. Sci. 75:1666-1673.

Buckland, P.C. 1993. Peatland archeology: A conservation resource on the edge of extinction. Biodivers. Conserv. 2:513-527.

Bunt, A.C. 1988. Media and mixes for container grown plants. Unwin Hyman, London.

Byrne, P.J. and B. Carty. 1989. Developments in the measurement of air filled porosity of peat substrates. Acta Hort. 238:37-44. 
Choi, J.M. and P.V. Nelson. 1996a. Development of a slow-release nitrogen fertilizer from organic sources. II. Using poultry feathers. J. Amer. Soc. Hort. Sci. 121:634-638.

Choi, J.M. and P.V. Nelson. 1996b. Development of a slow-release nitrogen fertilizer from organic sources. III. Isolation and action of a feather degrading actinomycete. J. Amer. Soc. Hort. Sci. $121: 639-643$.

Chong, C. and R.A. Cline. 1993. Response of four ornamental shrubs to container substrate amended with two sources of raw paper mill sludge. HortScience 28:807-809.

Evans, M.R. 2004. Processed poultry feather fiber as an alternative to peat in greenhouse crops substrates. HortTechnology 14:176-179.

Evans, M.R. and R.H. Stamps. 1996. Growth of bedding plants in Sphagnum peat and coir dust-based substrates. J. Environ. Hort. 14:187-190.

Fraser, R.D.B. and T.P. Macrae. 1980. Molecular structure and mechanical properties of keratins. Symp. Soc. Exp. Biol. 342:211-246.

Hadas, A. and L. Kautsky. 1994. Feather meal, a semi-slow-release nitrogen fertilizer for organic farming. Fert. Res. 38:165-170.
Jenkins, J.R. and W.M. Jarrell. 1989. Predicting physical and chemical properties of container mixtures. HortScience 24:292-295.

Klock-Moore, K.A. 1999. Bedding plant growth in greenhouse waste and biosolid compost. HortTechnology 9:210-213.

Klock-Moore, K.A. 2001. The effect of controlled release fertilizer application rates on bedding plants containing compost. Compost Sci. Util. 9:215-220.

Laiche A.J., Jr. and V.E. Nash. 1990. Evaluation of composted rice hulls and a lightweight clay aggregate as components of container-plant growth media. J. Environ. Hort. 8:14-18.

McGovern, V. 2000. Recycling poultry feathers: More bang for the cluck. Environ. Health Perspect. 108:8.

Moritz, J.S. and J.D. Latshaw. 2001. Indicators of nutritional value of hydrolyzed feather meal. Poult. Sci. 80: 79-86.

Nelson, P.V. 2003. Greenhouse operation and management. 6th ed. Prentice Hall, Upper Saddle River, N.J.

Palmquist, D.M., M.R. Weisbjerg, and T. Hvelplund. 1993. Ruminal, intestinal and total digestibilities of nutrients in cows fed diets high in fat and undegradable protein. J. Dairy Sci. 76:1353-1364.
Raymond, D.A., C. Chong, and R.P. Voroney. 1998. Response of four container grown woody ornamentals to immature composted media derived from waxed corrugated cardboard. Compost Sci. Util. 6:67-74.

Robertson, R.A. 1993. Peat, horticulture and environment. Biodivers. Conserv. 2:541-547.

Tan, T.C. and M.Y. Tai. 1983. Amino acids from poultry feather waste. Can. Inst. Food Sci. Technol. J. 16:148-150.

Tyler, H.H., S.L. Stuart, T.E. Bilderback, and K.B. Perry. 1993. Composted turkey litter: II. Effect on plant growth. J. Environ. Hort. 11:137-141.

U.S. Department of Agriculture. 2003. Poultry: Production and value, 2002 summary. U.S. Dept. Agr., Natl. Agr. Stat. Serv., Washington, D.C.

Wang, Y. 1991. Evaluation of media consisting of a cotton waste for the production of tropical foliage species. J. Environ. Hort. 9:112-115.

Wang, Y.T. 1994. Using ground kenaf stem core as a major component of container media. J. Amer. Soc. Hort. Sci. 19:931-935. 